\title{
TÉR, INFORMÁCIÓ ÉS TÁRSADALOM: A TÁRSADALOM TERÜLETI KUTATÁSÁNAK TÉRINFORMATIKAI ESZKÖZTÁRA ${ }^{1}$
}

\author{
(Space, Information and Society: \\ GIS tools in Spatial Research of the Society)
}

\section{JAKOBI ÁKOS}

\begin{abstract}
Kulcsszavak:
területi elemzés térinformatika regionális modellek térbeli mũveletek térbeli információ

A térinformatika nyitása, illetve az egyes szakmák által a térinformatikában rejlö lehetöségek felismerése új diszciplináris kapcsolatok kialakulásához vezetett és vezethet. Kimondottan erös kapcsolatokat lehet feltételezni a térbeli adatokat amúgy is fontosnak tartó földrajzi szakteriuletek és a térinformatika között. Ezen kapcsolatokból a társadalomföldrajz sem akart kimaradni, amely látszólag régi kapcsolatban van ezzel a szakággal, valojában azonban ez a kapcsolat inkább újszerünek mondható. Az eddigi felszines találkozások után ma már a mély együttmüködés jelei látszódnak kirajzolódni.
\end{abstract}

Az ezredforduló környékének informatikai robbanása a korábban a számítástechnikával nem sok kapcsolatot mutató szakmákat és szakterületeket is megfertőzte a digitális megoldások használatának lehetöségeivel. Az informatikai eszközök gyors térhódítása részben a korábban már alkalmazott eljárások és módszerek kivitelezésének felgyorsulását, másrészt új, korábban nem ismert technológiák kialakulását hozta magával.

Az informatikai fejlődéssel párhuzamban, illetve annak folyományaként eröteljes fejlödésnek induló térinformatika a fentiekhez hasonlóan kettös fejlődést indukált: a területi adatok kezelésének felgyorsulását, illetve az adatkezelés új megoldásainak kiformálódását. Ezek az új eljárások és eszközök a területi adatokkal foglalkozó diszciplínák mindegyikére hatással voltak, köztük a társadalomföldrajzra is. A társadalomföldrajzi elemzési eszköztárban manapság új hullámként jellemzett térinformatikai módszerek a földrajz ezen ágának erőteljes és dinamikus megújulása irányába hatnak.

A térinformatika irányába nyitó társadalomföldrajz és a társadalmi elemzések irányába nyitó térinformatika fejlödésében olyan új módszerek és eljárások kialakulását figyelhetjuk meg, amelyek az egyes diszciplínák saját szemszögéből nézve a másik szakterület eszközeit és eljárásait hasznosítják. Az efféle újítások egyben szemléletbeli változást is hozhatnak, illetőleg új fejlödési irányok kialakulását eredményezhetik.

A területi folyamatok vizsgálatával foglalkozó elméleti kutatók egy jelentős része a térinformatikát a modern területi elemzési áramlatai egyikének, a kvantitatív földrajznak a részeként vagy szinonimájaként értelmezi (Anselin 2000). Valójában a GIS a kvantitatív földrajzhoz hasonló, rendszerezett adatfeldolgozó módszerekböl tevődik össze, annyi különbséggel, hogy itt a hangsúly a kvalitatív elemzés irányába 
Jakobi Ákos : Tér, információ és társadalom : A társadalom területi kutatásának térinformatikai eszköztára. Tér és Társadalom 21. évf. 2007/1. 131-143. p.

is mutat eltolódásokat. A térinformatika tehát egy módszer arra, hogy beemeljük a földrajzba a modern tudományok trendjeit, ahogyan azt a kvantitatív módszerek a hatvanas-hetvenes években tették.

A térinformatika nyújtotta új lehetőségek felismerése a társadalomföldrajzi kutatásban tehát indokolt, a valódi széles körü ismertség és elterjedés azonban csak napjainkban indult meg. Ennek hátterében az általános informatikai fejlödés és nyitás mellett az az igény is nagy szerepet játszott, hogy összetettebb társadalomföldrajzi kérdésekre is válaszolni tudjunk. Ehhez nagy térbeli adat- és információmennyiségre volt szükség, továbbá számítógépre és egy olyan eljárásra, amely ezt az információhalmazt rendszerezni, kezelni, feldolgozni és elemezni tudja. A térinformatikában tehát a nagyszámú területi társadalmi-gazdasági adat és a számítógépes elemzési lehetöségek ötvözését akarták kihasználni első körben a geográfusok, amihez persze további igények és felhasználási lehetőségek is kapcsolódtak. A sok közül csak egyet említve a megjelenítés, azaz a digitális társadalomföldrajzi tematikus térképekben rejlő új lehetőségek is segítették a térinformatika és a társadalomföldrajz kapcsolatának fejlődését.

Természetesen mérlegelhetö, hogy mit tekintünk ismertségnek a társadalomföldrajz részéről. A térinformatika ugyanis már régóta foglalkozik olyan témákkal, amely közel áll a társadalomföldrajz gondolatvilágához (Mészáros 2000). A térinformatikában alapeszközként kezelt térképek a társadalomföldrajznak is alapelemei, a területi adatokkal való analízis mindkét szakterületre régóta jellemzö. A kapcsolat újszerüsége és az ismeretség fiatal jellege inkább a társadalomföldrajzi kutatói gondolkodás átalakulásában és új hullámában keresendő. A 20. század végének társadalomföldrajzosai - pontosabban egy jelentös csoportjuk - a számítógépet már nem csak mint kiegészítő eszközt használták, hanem mint a térbeli összefüggések vizsgálatának legfontosabb infrastrukturális elemét alkalmazták. Ez a generáció már nem riadt vissza a számítógép modernitásától, sőt kutatásai szolgálatába állította azt.

Valószínüleg nem vezetett volna messzire a térinformatika és a társadalomföldrajz kapcsolata akkor, ha kizárólag a korábban alkalmazott módszerek és lehetőségek megújítására vagy megismétlésére nyílt volna lehetöség. A két tudományág inkább szimbiotikusan közelített egymáshoz, azaz kölcsönösen és előnyösen hatott egymás fejlödésére. A társadalom területi kutatásába a térinformatika egyértelmủen új elemzési lehetőségeket hozott, eddig soha nem látott módszerek, modellek és eljárások váltak ismertté, míg a térinformatika részéről a diszciplína szerves fejlődését és egyre szélesebb körú elismertségét hozta az egyre több társadalmi-gazdasági tartalmú területi téma feldolgozása.

A társadalomkutatatási alkalmazott térinformatika kialakulására számos, különböző diszciplína hatott, mindegyik más-más részelemét kiemelve az új lehetőségeknek. A háttérben az egyes önálló szakterületek fejlödését tapasztalhattuk, miközben szépen lassan kiformálódott a társadalomföldrajzi térinformatika vagy a társadalmi területi kutatások térinformatikai eszköztára. Nagy hatással volt a fejlődésre például a közgazdaságtan területi elemzési kultúrájának fejlődése, amely igazán dinamikus volt az 1940-es és 1950-es évektől kezdődően (lásd pl. Geary 1954 vagy Moran 1948). 
Jakobi Ákos : Tér, információ és társadalom : A társadalom területi kutatásának térinformatikai eszköztára. Tér és Társadalom 21. évf. 2007/1. 131-143. p.

Fontos mozgatóerỏ volt az igény az olyan új elméleti szerkezetek kialakítására, amelyek határozottan bevonják a teret a társadalmi (gazdasági) folyamatok vizsgálataiba. Az effajta megközelítések közül jó néhány azokra a modellekre hasonlít, amelyeket a gazdaságföldrajzosok és a regionális kutatók már az 1960-as években javasoltak, kiemelve a hely, a szomszédság, a régió vagy a területi kapcsolatok jelentőségét. A térben lejátszódó társadalmi-gazdasági folyamatok és jelenségek informatikai (azon belül is térinformatikai) eszközökkel való elemzésének egyik jelentös hajtóerejét a közgazdaságtan szakterületei, a területi statisztika, a térökonometria és a térgazdaságtan képezték.

A társadalom területi kutatásában alkalmazott térinformatika kialakulásához és jövöbeli továbbfejlődéséhez járult hozzá az áramlat is, amely a térinformatika térképezési feladatain messze túlnyúló alkalmazásokban véli felfedezni az új lehetőségeket. A térinformatika és a társadalomkutatás kapcsolatának további potenciális fejlődését eredményezi, illetve eredményezheti a társadalom sajátos elméleti jellegü belső tereinek térinformatikába való integrálása vagy egyáltalán értelmezése (például a társadalmi távolságok vagy a gazdasági távolsâg stb. fogalmainak értelmezésével). Luc Anselin szerint ugyanilyen hatást, tehát a térinformatika és a társadalomkutatás közeledését eredményezi az is, ahogyan egyre szélesebbé válik mindkét szakterület analitikai eszköztára (Anselin 2000). Az önálló fejlődés mellett a kölcsönös egymásra hatás nemcsak a másik szakterület módszerének vagy közelítésmódjának átvételét jelentette, hanem az eddig fel sem merült vizsgálati problémák megoldásának esélyét is.

A társadalom és a gazdaság különféle részelemeivel foglalkozó kutatások és a térinformatika közeledése kiemelt jelentőségü mozgatóerő volt a 20. század második felében. Az automatizált kartográfia és a komplex grafikus tartalmak térképezésének lehetôvé válásával óriási fejlödési potenciál keletkezett a társadalmi-gazdasági adatok területi elemzése terén, miközben a térinformatika is profitálhatott abból, hogy a különféle adatelemzési eljárások módszereit beintegrálhatta saját szakterületébe. Ilyen hatású volt Michael Goodchild szerint például a területi adatmátrix alkalmazásának elterjedése, mely nem volt más, mint olyan társadalmi-gazdasági adattáblák alkalmazása, melyeknek utolsó oszlopai a térbeli referencia-adatokat tartalmazták (Goodchild 2004). Hasonló hatást tapasztalhattunk a területi modellek, modell-elméletek elterjedésekor is.

A kár paradoxnak is tekinthető módon, a térinformatika és a társadalomföldrajz közeledésére az egyik legnagyobb hatást nem társadalomtudományi, inkább természettudományi szakterület gyakorolta. A térinformatikai alkalmazásokban rejlő lehetőségeket a természetföldrajz valamivel hamarább felismerte, s ez a diszciplína volt az, amelytől a társadalomföldrajz - ezen a téren - sokat tanulhatott. Mára a természetföldrajz legtöbb kutatási területén a térinformatika elfogadott, sőt alapmódszerré vált, míg a társadalomföldrajzban ettöl még (itthon mindenképp) egy kicsit távol vagyunk. A természetföldrajzban alkalmazott térképezési eljárásoktól kezdve a számítási technikákon keresztül a komplex modellező alkalmazásokig sok helyütt 
Jakobi Ákos : Tér, információ és társadalom : A társadalom területi kutatásának

térinformatikai eszköztára. Tér és Társadalom 21. évf. 2007/1. 131-143. p.

hasznosítják a térinformatika módszereit, melyekböl jó néhány a társadalomföldrajzba is átszivárgott ${ }^{2}$.

Összefoglalva, a társadalomföldrajzi térinformatika kialakulásának történetében az alábbi szempontok játszottak jelentős szerepet:

- A 20. század végének általános informatikai fejlödése és az ún. informatikai forradalom.

- A tudományos kutatásokban bekövetkezett kvantitatív forradalom és az ennek eredményeként kialakuló részdiszciplínák fejlödése (kvantitatív földrajz, területi statisztika, térökonometria stb.).

- Az interdiszciplinaritás és a szakterületek konvergenciájának erösödése, a tematikus specializáció iránti igény növekedése.

- A társadalomföldrajzi módszertan fejlödése, a rokontudományok módszereinek adaptálási kísérletei.

\section{A társadalomföldrajzi térinformatika értelmezései.}

A társadalomföldrajzi térinformatika tárgya - amint azt megannyi más interdiszciplináris szakterület esetében is tapasztalhatjuk - nehezen körvonalazható. Nincs egyértelmü és elfogadott definíciónk arról, hogy mi tartozik a társadalomföldrajzi térinformatika körébe és mi nem, de ez nem jelenti azt, hogy ne lehetne jellegzetességeket, jellemzőket megfogalmazni a társadalom térinformatikai eszközökkel segített területi elemzését illetően.

Szakirodalmi tapasztalatok szerint attól függően, hogy mely kutató, milyen irányból közelít a téma felé, más és más hangsúlyokban fordul elő a társadalmi és a térinformatikai motívum. Nicholas Chrisman például geográfusként (területi kutatóként) szorgalmazza a térinformatikai eszközök alkalmazását (Chrisman 2005), míg ellenpéldaként Massimo Craglia idézhetỏ, aki a térinformatika irányából fogalmazza meg a nyitás igényét a társadalmi vizsgálatok felé (Craglia 2000). A konklúziók nem egyértelmủek a kérdést illetően, hiszen a szakirodalomban mára egyértelművé vált a két szakterület ilyen irányú összefonódása. Az is látható, hogy mind a térinformatika mind a társadalomföldrajz hatott a másik szakterületre, ezért a társadalomföldrajzi térinformatikát érintő fejlödésük inkább együttes volt és nem egymás utáni. Természetesen kiragadható egy-egy példa, amely geográfus vagy térinformatikus részről jelentösebb lökést adott a közös szakterület kialakulásának, de a fejlódést inkább folyamatnak és folyamatosnak tekinthetjük, amiből az következik, hogy a társadalomföldrajzi térinformatika a térinformatika és a társadalomföldrajz (a társadalom területi kutatása) határterületén lévö új és kialakulóban lévó alkalmazott irányzat.

A társadalomföldrajzi térinformatika tárgyát illetően is megoszlanak a vélemények. Sokak szerint nagyjából egyértelmü, hogy társadalomföldrajzi térinformatika alatt a térinformatika technikáinak alkalmazását értjük valamilyen társadalmi jelenség területi vizsgálatában. Ezt a nézetet képviseli például Luc Anselin (1999) vagy Keiji Yano (2001), akik tehát a térinformatikát mint eszközt vagy mint módszertant, a társadalomföldrajzot pedig mint elemző, értékelő vagy témafelvető szempontot 
veszik figyelembe. A társadalomföldrajzi térinformatika egy másik értelmezése az, amikor társadalmi adatokat kezelö térinformatikai rendszerek vagy területi információs rendszerek formájában beszélünk a témáról. Ilyenkor a komplex térinformatikai struktúrán belül csak maguk az adatok számítanak társadalmi tartalmúaknak, míg minden egyéb a hagyományos értelemben vett térinformatikai megoldások tárgykörébe tartozik. Jellemzöen ezt a nézetet képviselik azok, akik a térinformatika irányából közelítve a társadalmi adatfeldolgozás és adatértékelés céljából figyeltek fel erre a lehetőségre. Ilyen alkalmazó például Prajczer Tamás (2004), aki választási adatokat elemez térinformatikai környezetben.

Ha elfogadjuk azt a nézetet, hogy a társadalomföldrajzi térinformatika a térinformatikai módszerek és a társadalmi adatok képletesen mondott integrációját emeli ki, akkor is még mindig több különálló megközelítést, eltérö értelmezést tapasztalhatunk a szükebb értelemben vett vizsgálati tárgykört illetỏen. Ezek a nézetkülönbségek leginkább abból adódnak, hogy mit tekintünk térinformatikai és mit társadalomföldrajzi témának.

A fentiek szintézise alapján a társadalomföldrajzi térinformatikának képesnek kell lennie a társadalmi-gazdasági adatok elemző és értékelő feldolgozására egy olyan informatikai környezetben, amely az adatok gyüjtésétől kezdve azok tárolásán és feldolgozásán át egészen a strukturált megjelenítésig minden funkciót képes ellátni.

\section{Feltételrendszer, adatszükséglet}

Minden társadalomföldrajzi kutatás alapvetỏen a társadalom jellemzöit leíró adatokkal foglalkozik, melyeket a földfelszín megfelelő pontjaihoz viszonyítva vizsgál. Valójában azonban jóval több adattípussal dolgozunk egy társadalmitérinformatikai vizsgálat alkalmával.

A társadalom térinformatikával támogatott területi kutatásához alapvetően négyféle adatra van szükség:

- az első adattípust a társadalom és a gazdaság általános folyamatairól szóló térfüggetlen vagy térmentes adatok képezik,

- a második típusba a területi társadalmi-gazdasági adatok tartoznak,

- a harmadik csoportot a digitális alaptérképi adatok képezik,

- míg a negyediket $a$ módszertanhoz kapcsolódó adatok.

A térinformatikai eszközök használatával valóságos kapcsolatban lévő adatok a társadalomföldrajzi vizsgálatokban azok lesznek, amelyek valódi földrajzi tartalommal is bímak. A térbeli adatok földrajzilag lokalizálják a társadalmi-gazdasági elemeket, s ezzel olyan többletinformációkat is tárolnak, amelyek a geográfiai elemzések elengedhetetlen és sajátos részéül szolgálnak. Az adatinfrastruktúra szempontjából a térbeli adatoknak két meghatározó elemét kell kiemelnünk: a területi társadalmi-gazdasági adatok csoportját és a megjelenítést és lokalizációt segitő digitális alaptérképi adatok csoportját. A területi társadalmi adatok képezik a társadalom és a gazdaság kutatásának esszenciális elemeit, míg a digitális alaptérképi 
Jakobi Ákos : Tér, információ és társadalom : A társadalom területi kutatásának

térinformatikai eszköztára. Tér és Társadalom 21. évf. 2007/1. 131-143. p.

adatok a térinformatikai lehetőségek legfontosabb meghatározói. Mindkét csoport természetesen - önmagában is rendkívül átfogó jellegű, sok belső részterületre osztható. A társadalomföldrajzi alapadatok esetében nem csak a vizsgálati adat tartalma és minösége, de annak térségi szintje (település, kistérség, megye, régió, ország stb.) is meghatározó jelentőségú. A digitális alaptérképi adatok esetében a tartalmi és minőségi tulajdonságokon túlmenően a kiegészítő, kapcsolódó adatok és információk (pl. vetületi rendszerek, referenciák stb.) szerepe is lényeges.

A társadalomföldrajzi térinformatikai rendszer dominánsan elemzö funkciójú, amely egy megfelelő területi társadalmi-gazdasági adatbázisra és az azt kiegészítő geoadatok halmazára épül. A társadalom területi kutatásához szükséges elemzö térinformatikai rendszer alapját képezỏ földrajzi és társadalmi-gazdasági adatok a GIS felépítésének első és egyben egyik legfontosabb lépéséhez kapcsolódnak. Ugyanígy fontos szerepe van a megfelelő vizsgálati területröl szóló digitális alaptérképek kiválasztásának is. Nagyjából e két csoportba lehet besorolni a legfontosabb infrastrukturális input elemeket. További - külsỏ szakértői alapon meghatározott input definiálja a társadalomföldrajzi térinformatikai vizsgálatokban alkalmazott módszerek kiválasztását is.

A térinformatikai rendszerben a társadalmi-gazdasági adatok integrálása után és a megfelelő (döntően elemző) térinformatikai szakmódszer meghatározása után a térinformatikai outputok megjelenítésének fázisa következik. A végtermékekhez kapcsolódó szakértỏi elemzések, eredményértékelések a kezdeti fázisban kitủzött társadalomföldrajzi vizsgálati kérdések megválaszolására kínálnak esélyt.

\section{Térbeli müveletek a társadalom területi kutatásában}

A térbeli mủveletek a térinformatika tudományában tulajdonképpen egyet jelentenek a térbeli adatelemzés módszereivel. Egyes meghatározások szerint a térbeli múvelet olyan múvelet, amely átalakítja az adat értékét vagy formáját egy vagy több adatszinten (Márkus 2003). Más összefoglaló tanulmányok az elemzési, azon belül is az adatelemzési funkciók között foglalkoznak ezzel a témával (például Detreköi-Szabó 2002).

Az egyszerủ kérdések megválaszolása, az egyszerü müveletek alkalmazása a térbeli adatelemzés - nomen est omen - legegyszerúbb módját jelenti. A szakirodalom egyszerú térbeli mủveletnek olyan müveleti eljárást tekint, amely egy idöben csak egy adatszintet érint (Márkus 2003). Az egyszerủség azonban nem jelenti a bonyolultabb kérdések kikerülését, egyes eljárások ugyanis lehetőséget biztosítanak a más módszerekkel nem, vagy csak nehezen megoldható feladatok elvégzésére is. A társadalomföldrajz éppen ebben a motívumban - tehát a bonyolultnak látszó kérdések egyszerú megoldásában - látja a térinformatika alkalmazásának egyik legnagyobb előnyét. Az egyszerủ mủveletek mindazonáltal valóban könnyebben kivitelezhetô elemzési eljárásoknak számítanak mind a szoftver, mind a felhasználói ismeretek szempontjából. 
Jakobi Ákos : Tér, információ és társadalom : A társadalom területi kutatásának térinformatikai eszköztára. Tér és Társadalom 21. évf. 2007/1. 131-143. p.

Az egyszerü műveletek között olyan eljárásokat fedezhetünk fel, mint a lekérdezés, a kicsinyítés, nagyítás, az útirány-meghatározás, a távolság-, a terület- vagy a kerületszámítás, a centroid-meghatározás, a közelségszámítás vagy a klasszikus szomszédsági mủveletek (pl. övezetgenerálás, szürök stb.). Ezek az eljárások a térinformatikai rendszerben tárolt földrajzi helyzet és társadalmi-gazdasági attribútum ismeretében hajtják végre a feladatként szabott müveleteiket tulajdonképpen egy térbeli egyenletmegoldás formájában ${ }^{3}$.

Az egyetlen térinformatikai adatszintet érintô mủveletek többsége a társadalomkutatók számára már részben ismert lehet, de sokszínủségükböl adódóan ezek a mủveletek a térinformatikai környezetben az eddigieknél jóval több lehetőséget kínálnak. Az egyszerü eljárások közé sorolt geometriai múveletek, a távolság, az irány, a terület, a kerület vagy a térfogat meghatározása a térinformatikai rendszerben eleve tárolt helyzeti és topológiai információkat előnyösen használhatják ki, következésképpen a GIS technológiák hasznosítása eredményes lehet.

Némely egyszerü térinformatikai eljárás, például az övezetgenerálás módszere eddig csak ritkábban avagy közvetve fordult elő a társadalmi kutatásokban. A szomszédsági múveletek közé tartozó övezetgenerálási módszer alkalmazásakor a tér azon pontjait keressük egy entitás körül, amelyek az eredeti alakzattól számítva egy adott távolságon belül helyezkednek el. A puffer-zóna néven is ismert övezet létrehozásakor előre megszabott állandó távolságértékkel vagy az egyes objektumokhoz kapcsolódó attribútumok értékének függvényeként alakuló távolságértékek alapján határozhatjuk meg a zónahatárt. A társadalom területi kutatása számára mindkét változat kínál alkalmazási lehetöségeket, amelyeket az egyes vizsgálati kérdésekhez kapcsolódva igen sokszínüen lehet megoldani.

Más szomszédsági vizsgálatok is felismerték a térinformatikai technikákban rejlö lehetőségeket. Míg korábban a szomszédsági vizsgálatokhoz használatos mátrixokat a térképi információk manuális méréseivel illetve leolvasásával lehetett elkészíteni, addig a térinformatika korában ezt már a szoftverek oldják meg. A térinformatikai számítások egy jelentős részében a szomszédsági mátrix már nem is jelenik meg a felhasználó elött a képernyőn, mindössze a számítások elméleti hátterében létezik. E GIS mủveleteknél a felhasználó mindössze a vizsgálati módszert és a vizsgálatba bevonandó változókat kell, hogy definiálja, majd bármiféle közbülsó lépés nélkül várhatja az eredményeket. Az erre épülỏ megoldások - például a területi autokorreláció különféle számítási módszerei - gyakorta már eleve integrált formában hasznosítják a térinformatikai technikákat. A területi autokorreláció módszerei a nagy számításigényủ szomszédsági mủveletek közé tartoznak, ezért kifejezetten népszerúek azok a térinformatikai programok, modulok vagy kiterjesztések, amelyek képesek kezelni az ilyen feladatokat. Ezt a lehetỏséget kínálja például az ArcView szoftver néhány speciális kiterjesztése, illetve a tipikusan társadalmi területi elemzésekre alkalmas Geoda, illetve SpaceStat programok.

A térbeli müveletek széles körén belül külön csoportot képviseḷnek az ún. összetett müveletek, amelyek egyszerre több adatszintről származó adattal dolgoznak. Tulajdonképpen ebben a lehetőségben áll a térinformatika egyik nagy erőssége, 
Jakobi Ákos : Tér, információ és társadalom : A társadalom területi kutatásának

térinformatikai eszköztára. Tér és Társadalom 21. évf. 2007/1. 131-143. p.

hiszen itt olyan adatintegrációs feladatokat kell elvégezni, amelyet a hagyományos eljárások képtelenek voltak megoldani, vagy csak nehézkes módszerekkel tudtak kivitelezni. A probléma leküzdéséhez ugyanis rendszerszemléletủ informatikai megoldásra van szükség, amely képes egy kiemelt szemponthoz, ez esetben a földrajzi pozíciót leíró helyzeti információhoz kötni a különbözö forrásokból származó attribútum jellegú másodlagos információkat. Itt tehát a térbeli adatbázis-kezelés egy olyan feladatával állunk szemben, amikor a geográfiai információn keresztül tudjuk összekapcsolni a különbözỏ leíró információk tábláit.

Az összetett müveletek esetében a különbözỏ adatforrásokból vagy adatszintekböl származó adatok összekapcsolása nagy kihívást jelent, ugyanakkor kifejezetten sok szép és izgalmas lehetöséget is kínál a területi adatelemzésre. A társadalomföldrajzi vizsgálatok többsége eddig kevésbé használta ki a több adatszint együttes kezelésében rejlö lehetöségeket, így ezen a téren bőven akadnak még muníciók a továbbfejlödésre.

$\mathrm{Az}$ összetett müveletek egyik leggyakrabban elöforduló csoportját a különbözö átlapolási módszerek képezik. A térinformatika ezen funkciója kiemelt jelentőségü, mivel egy olyan sajátos adottságnak tekinthetö, amely megkülönbözteti a GIS-t az olyan alapvető informatikai rendszerektől, mint például a CAD vagy a DBMS. A rétegmüvelet néven is ismert eljárás két különbözö típusú területi adat együttes konfigurációját veszi figyelembe az elemzés során. A különböző rétegmetszési müveletek végeredményeként olyan új attribútum-információk keletkezhetnek, amelyek hasznos alapjai lehetnek a későbbi társadalomföldrajzi kalkulációknak.

A térinformatika klasszikus módszerei közé tartozó interpolációs és felületgeneráló eljárások iránt az utóbbi években a társadalomföldrajz irányából is megindult az érdeklődés. Sorra születnek az olyan publikációk, amelyek közvetve vagy közvetlenül használják ki a térinformatika eme igen fontos módszerét. Az interpolációs eljárások népszerüségét többek között a látványos eredményekben és a rendkívül sokszínü alkalmazási lehetőségekben ismerte fel a társadalom területi kutatásával foglalkozó szakma, de ezen felül nem elhanyagolható az sem, hogy az effajta eljárásokkal régóta meglévő kérdések megválaszolására és új ötletek megalkotására is lehetőség nyílt. A módszer igazi jelentösége ott látszik, hogy új perspektívát nyit meg a társadalmi jelenségek területi elemzéseiben.

A társadalomföldrajzi kutatók a módszerben rejlö kettősséget - azaz a megjelenítés és az elemzés együttes lehetőségét - nagy leleménnyel a saját gondolkodásmódjuk, problematikáik megoldásai szolgálatába állították. Tanulva és okulva a domborzatmodellek természetföldrajzi alkalmazási lehetőségeiböl a korábban kialakított módszerek adaptálása után csak az új vizsgálati kérdést kellett megfogalmaznia a társadalomtudománynak, amely tehát nem természeti, hanem társadalmi problémák kutatására teszi megfelelővé ezt a módszert. A társadalom területi jellegzetességeit vizsgáló kutatók és kutatási módszerek - a 20. század végére és a 21. század elejére amúgy is jellemző - nyitottsága más tudományágak bevált módszerei irányába is megmutatkozott már (lásd fizikai analógián alapuló módszerek, Nemes Nagy 1998). A legegyszerúbb módon a vizsgálati adatokat természetiröl társadalmira cserélték a kutatók ez esetben, feladatot, illetve kihívást pedig az eredmények értelmezése jelentett csak. 
A térinformatika interpolációs és felületgeneráló eljárásainak tárháza igen sokszínủ. Némelyek kevésbé, mások azonban annál jobban kapcsolódhatnak egyes társadalomföldrajzi kutatásokhoz. A felületkészítés régóta alkalmazott módszere például a trendfelület-elemzés, melyet már a társadalomföldrajzi kutatások is felismertek. Hasonlóképpen a térbeli mozgóátlaggal generált társadalmi feluletek sem jelentenek tökéletes újdonságot (lásd pl. Grasland-Madelin 2001). Mindezen tapasztalatok ellenére a térbeli interpolációs technikák térinformatikai alkalmazásai a társadalom területi kutatásában még igen gyermekcipőben járnak. Megemlíthetỏ a térinformatikában már klasszikusnak számító Thiessen (Dirichlet, Voronoy)interpoláció társadalmi kontextusú hasznosítási lehetősége, vagy az úgynevezett szakadásos felszín-modellek társadalomföldrajzi alkalmazási lehetősége, mint potenciális új társadalmi térinformatikai módszer.

Külön említést érdemel a térinformatikában kartográfiai modellezés néven ismert eljárás is, amely tulajdonképpen egy általános módszer a térinformatikai eljárások grafikus összerendezésére. A térképi algebra vagy a „mapematika” kifejezésekkel gyakorta összhangba hozott eljárás grafikus megközelítést kínál fel az adatszintek integrálásához és elemzéséhez, ami jelentősen hozzájárul a térbeli döntéstámogatás tervezéséhez (Márkus 2001). Gyakorlati kivitelezését tekintve a kartográfiai modellezés eredményei többnyire egy folyamatábrához hasonlítanak, miközben lényegi feladatuk a különféle adatszinteken és azok között végzett számítások és mủveletek összerendezése és sorrendjének megtervezése szokott lenni. A kartográfiai modellezés gondolatmenetéböl kiindulva a társadalomföldrajzi vizsgálatok is sok tekintetben többlépcsős folyamatként értelmezhetők. Gyakori, hogy több különböző adathalmazon és több eltérỏ módszerrel elvégzett vizsgálatsorozattal juthatunk el a társadalmi jelenség kívánt szintü megértéséhez, ezért a térinformatika ilyen típusú gondolkodásmódja igen hasznos lehet a társadalomkutatók számára is.

A folyamatszerú modellezés során a matematikai gondolkodásmód kerül elötérbe. $\mathrm{Az}$ algebrai egyenletekhez hasonlóan itt a térképek képezik az egyenletekben szereplő változókat, míg a térbeli műveletek jelentik a függvényeket (1. ábra). Másként fogalmazva a kartográfiai modellezés a térképeket és a térkép komponenseit úgy tekinti, mint egy algebrai egyenlet részeit.

A térinformatikában alkalmazott térbeli elemzési mủveletek további jelentős csoportját képezik a hálózati müveletek. A térinformatikai alkalmazások ezen kedvelt vizsgálati módszere, a hálózatelemzés alapvetỏen a hálózati topológia vizsgálatához kapcsolódik. Az ilyen kutatások olyan térbeli rendszereket vizsgálnak, amelyek vonalas és csomóponti elemek szövevényeként jellemezhetők. A napjainkban egyre divatosabbá váló hálózatok belsỏ szerkezetét, az alkotóelemek egymáshoz viszonyított helyzetét és az elemek közötti kapcsolatokat vizsgálhatjuk ezzel a módszerrel.

Bár ez a vizsgálati módszer alapvetően a müszaki-technikai infrastruktúra elemzéséhez kötődően vált ismertté (természetesen sok egyéb alkalmazási lehetösége is létezik), ennek ellenére a társadalomföldrajz nem csak az infrastrukturális elemek kapcsán tudja hasznosítani az effajta technikákat, mindazonáltal a leggyakoribb infrastrukturális kontextusú elemzések a társadalomföldrajzot is érdeklik. Az úthálózat vagy a 
Jakobi Ákos : Tér, információ és társadalom : A társadalom területi kutatásának

térinformatikai eszköztára. Tér és Társadalom 21. évf. 2007/1. 131-143. p.

telekommunikációs hálózatok, mint hálózati rendszerek klasszikus vizsgálati terepei az elérhetöségi kutatásoknak. A térinformatikai rendszerekbe szervezett feladatmegoldások így könnyen kideríthetik, hogy hol találhatók például a legnehezebben, leghosszabb idő alatt elérhető, vagy a leginkább periférikus helyzetủ elemek stb.

\section{1. ÁBRA}

A népességszám-változás logikai vizsgálata a soproni kistérségben „mapematikai” módszerrel

(Logical Investigation of Population Change in the Sopron Microregion with Methods of "Mapematics")

(ha $\mathrm{a}-\mathrm{b}<0$, akkor $\mathrm{c}=1$; ha $\mathrm{a}-\mathrm{b}>0$, akkor $\mathrm{c}=0$ ) (if $\mathrm{a}-\mathrm{b}<0$, than $\mathrm{c}=1$; if $\mathrm{a}-\mathrm{b}>0$, than $\mathrm{c}=0$ )
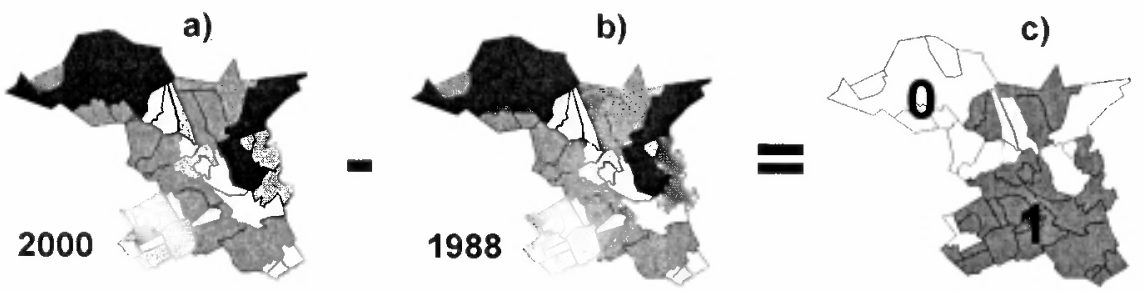

Forrás: Saját szerkesztés.

A társadalom térbeli sajátosságait kutató hálózatelemzési módszerek egy speciális alkalmazási területét képezik a társadalmi mikroterekben, a társadalom belső terében végzett vizsgálatok. A térinformatika szerepe ilyen esetekben közvetett, illetve még nem teljesen kiforrott, mégis érdekes eredményeket kínálhat a társadalomkutatók számára. A társadalmi csoportok belső hálózatának vizsgálatakor az egyes megfigyelési egységek vagy alapelemek (például személyek) képezik a csomópontokat, míg a kapcsolatok a vonalakat. Ezen vonalaknak azonban nem vagy csak átvitt értelemben értelmezhető a hossza, ezért a hálózati távolság vagy a legrövidebb út fogalmát itt egyszerúen az érintett csomópontok számával lehet leírni. Ha a térinformatika képes lesz arra, hogy a társadalom belső terének ilyen leképezését is kezelni tudja, akkor a társadalomföldrajzi térinformatika igazán újszerủ eredményeket kínáló versenyképes eszköz lehet a társadalomtudományban.

\section{Nem müveleti jellegü társadalomföldrajzi térinformatika}

Ha a GIS témakörét szélesen értelmezzük, akkor a térinformatika a múveleti, számítási eljárásokon túl mást is kínál a társadalom területi kutatói számára. Végső soron minden olyan eset szóba jöhet, amikor térbeli adatokról, azon belül a társadalom vagy a gazdaság térbeli szerveződésének bármiféle adatáról és ehhez kapcsolódóan informatikai eszközökkel támogatott adatfeldolgozásról van szó. Noha sokan elfeledkeznek róla, de a térinformatika nem csak GIS szoftverhasználatból áll, annál jóval bővebb tartalmú. 
Jakobi Ákos : Tér, információ és társadalom : A társadalom területi kutatásának térinformatikai eszköztára. Tér és Társadalom 21. évf. 2007/1. 131-143. p.

Laikusok vagy kezdö geográfusok, területi kutatók számára a térinformatikai eszközök alkalmazása társadalomföldrajzi kontextusban leginkább a tematikus térképek készítésében merül ki. Ez nem jelenti azt, hogy ez az eljárás kevesebb vagy alapvetően egyszerübb lenne a fent vázolt térinformatikai múveleteknél, de mindenképpen valószínüsíthetö, hogy ismertebb. Összefoglalóan a megjelenités témaköre leggyakrabban a társadalomföldrajzi adatok térbeli szemléltetésére alkalmas digitális tematikus térképek formájában köti össze a térinformatikát a társadalomelemzéssel.

A társadalomföldrajz különleges térképi ábrázolási technikái közé tartozik az ún. topologikus térképek módszere, amely tartalmi, megjelenítési és értelmezési formájában is jelentősen eltér a szokványos tematikus térképezési technikáktól. A térinformatika a topologikus térképek elkészítésében nagy segítséget nyújthat, mivel a térinformatikai gondolkodásmód jól passzol az eljárás kivitelezéséhez. Ismernünk kell egyrészt az eredeti területegységek topológiai relációit, amelyet számos térinformatikai szoftver, pontosabban adatmodell eleve is támogat. Térinformatikai eszközök segítségével továbbá könnyen kiszámítható a vizsgált társadalmigazdasági mutató értékével arányos terület nagysága is.

Az egyszerú eljárásoktól különválasztott bonyolultabb, összetettebb térinformatikai megoldások kiemelt figyelemre számíthatnak a modern társadalomföldrajz részéröl. Ezek az alkalmazások már-már a két szakterület összeolvadását sejtetik, valójában továbbra is arról van szó, hogy a társadalomföldrajz mint felhasználó igényeit a térinformatika mint eszköz próbálja kielégíteni. Más értelemben azonban a térinformatika az eszközökön túl fejlödési potenciált is jelenthet. A térinformatika egyre dinamikusabb fejlődése és egyre nagyobb ismertsége a társadalomföldrajz részéröl is felveti a magasabb színvonalú, több erőforrást igénylö, ugyanakkor számos újszerú lehetőséggel és eredménnyel kecsegtető komplex térinformatikai megoldások alkalmazásának igényét. Az egyszeri vagy alkalmankénti térinformatikai eszközhasználatot ezzel felválthatja a GIS-re épüló társadalomföldrajzi elemzés, ami ismételten jelzi a térinformatika hatalmas jelentőségét a társadalomföldrajz fejlödésében.

A társadalomföldrajz számára a térinformatika gyakorta nem csak eszközt, de szemléletmódot vagy gondolkodásmódot is jelent, ami például a feladatmegoldás és a problémamegoldás menetében válik nyilvánvalóvá. Mindenképpen le kell szögeznünk, hogy a térinformatika többet adott a társadalomföldrajznak a gyors és pontos számításokon és elemzési eljárásokon túl, aminek egyik legjobb példáját a térinformatika sajátos modellalkotási képességében fedezhetjük fel.

Szép példái lehetnek a térinformatika által támogatott vagy megvalósított társadalomföldrajzi modelleknek a települések belsö szerkezetét vizsgáló városmodellek. A településmorfológia, tehát az épületek, utak és egyéb létesítmények településen belüli szerkezetének, térbeli elhelyezkedésének vizsgálata fontos irányzatot képvisel a társadalomföldrajz egyik részterületén, a településföldrajzon belül. A térinformatika a két és háromdimenziós városmodellekkel lehetőséget biztosít a településmorfológia számára, hogy valósághủen, ugyanakkor egyes kitüntetett vizsgálati kérdéseket elötérbe helyezve elemezzen például bizonyos beépítés-sürüségi vagy funkcionális szerkezeti kérdéseket. 
Kiemelten fontos, hogy a térinformatika a különféle földrajzi információs rendszerek révén szoros kapcsolatban áll a rendszerszemléletü gondolkodásmóddal. Valamilyen szinten az eddig említett összes módszerben fel lehetett fedezni ezt az aspektust. A társadalom területi kutatásában alkalmazott rendszerszemléletü megoldások egyik legfontosabb tulajdonsága az alkotóelemek közötti összefüggésekben rejlik. Tulajdonképpen ez az a motívum, amelyben a rendszerszemléletủ megoldások többet képesek nyújtani a korábban említett müveleti és egyéb eljárásoknál. A rendszerelemek közötti összefüggések az egyes vizsgálati kérdéseket olyan új megvilágításba helyezhetik, amelyek eddig fel nem derített jelenségekre is rávezethetik a kutatókat.

$\mathrm{Az}$, ,igazi” vagy a kívánatos társadalomföldrajzi térinformatikai rendszer egymagában képes végrehajtani mindazokat a feladatokat, amelyeket egy társadalmi területi elemző és értékelő munka során el kell végezni. Ezek az adatgyüjtés, adatrögzítés, az adattárolás feladatai, továbbá az adatok ellenörzése, az adatok karbantartása, a döntéselökészitési feladatok támogatása (számítások, összesitések, elemzések) vagy a dokumentumok, jelentések készítése formájában fogalmazható meg. A rendszerszemléletü társadalomföldrajzi elemzésben tehát több összekapcsolódó feladatról, összerendezhetö lépésekröl lehet beszélni, amelyeket egy térinformatikai alapú szisztéma tart össze.

\section{Összegzés}

A társadalom és a térinformatika kapcsolatát több szempontból is vizsgálhatjuk. A fent bemutatottak leginkább azt a motívumot emelték ki, mely szerint a társadalomföldrajz a térinformatikára elsősorban mint módszertani megújító eszközre tekint. Egyértelmü tapasztalat, hogy a társadalom területi kutatásába a térinformatika egy új szemléletet is hozott a társadalmi térbeli problémák vizsgálatában. Az eredmények közül számos nem csak az új vizsgálati technikáknak köszönhetö, de annak is, hogy teljesen újszerủ gondolkodásmódban kellett elhelyezni a társadalom területi jellemzőinek vizsgálati kérdéseit. A társadalomföldrajzi térinformatika technikáival messze túl lehetett lépni a tematikus térképezés szintjén, és el lehetett jutni a szintetikus összetett vizsgálatokig, fenntartva persze, hogy a digitális tematikus térképezés is a feltörekvő társadalomföldrajzi alkalmazások közé tartozik.

Ha a társadalom területi kutatása lépést akar tartani a fejlődő tudományokkal és az információs társadalmi átalakulással, akkor számára is kihagyhatatlan az informatikai eszközök szerves integrálása saját gondolatvilágába (Mészáros 2000). Nem elégedhetünk meg azonban a számítógépek mindössze szövegszerkesztő vagy hasonló feladatokat ellátó programjainak alkalmazásával, annál magasabb szintre kell helyeznủnk az informatikai eszközök hasznosítását a társadalom területi kutatásában. Tulajdonképpen a térinformatika az, amely képes ezt a funkciót kielégíteni a társadalomföldrajz számára. 
Jakobi Ákos : Tér, információ és társadalom : A társadalom területi kutatásának

térinformatikai eszköztára. Tér és Társadalom 21. évf. 2007/1. 131-143. p.

TÉT XXI. évf. 2007 a 1

Tér, információ és társadalom

\section{Jegyzetek}

${ }^{1}$ A tanulmány a 2006. november 18-án, az ELTE-n tartott Regionális Modellek c. tudományos konferencián elhangzott elöadásra épül.

Más kérdés az, hogy a természttudományokbơl, a természetföldrajzból átvett eszközök, modellek társadalomföldrajzi adaptációjának elvi és elméleti korlátai még sok esetben nem teljesen kivitatottak (ehhez kapcsolódóan lásd a klasszikus gravitációs modellról Tagai Gergely tanulmányát).

${ }^{3}$ Ilyen jellegủ mủveletekre példák találhatók Horváth Eszternek, e folyóiratszámban közölt írásában.

\section{Irodalom}

Anselin, L. (1999) The future of spatial analysis in the social sciences. - Geographic Information Sciences. 5.67-76. 0 .

Anselin, L. (2000) The link between GIS and spatial analysis. - Journal of Geographical Systems. 2. 11-15. o.

Chrisman, N. (2005) Full Circle: More than just Social Implications of GIS. - Carographica. 4.

Craglia, M. (2000) GIS and the social sciences: a European perspective. Computers. - Environment and Urban Systems. 24. 273-282. o.

Detrekỏi Á.-Szabó Gy. (2002) Térinformatika. Nemzeti Tankönyvkiadó, Budapest.

Geary, R.C. (1954) The contiguity ratio and statistical mapping. - The Incorporated Statistician. 5. 115-145. o.

Goodchild, M.F. (2004) GIS and spatial data analysis: Converging perspectives. Papers in Regional Science. 83. 363-385. o.

Grasland, C.-Madelin, M. (2001) The unequal distribution of population and wealth in the world. Population et Sociétés. 368.

Haggett, P. (1967) Locational Analysis in Human Geography. - Economic Geography. 43. 276-277. o.

Krugman, P. (1998) What's new about the new economic geography? - Oxford Review of Economic Policy. 14. 7-17. o.

Márkus B. (2001) Bevezetés a térinformatikába. Nyugat-Magyarországi Egyetem, Geoinformatikai Főiskolai Kar, Székesfehérvár.

Márkus B. (2003) Térbeli müveletek. Nyugat-Magyarországi Egyetem, Geoinformatikai Főiskolai Kar, Székesfehérvár.

Mészáros R. (2000) A társadalomfóldrajz gondolatvilága. Szegedi Tudományegyetem Gazdaság- és Társadalomföldrajzi Tanszék, Szeged.

Moran, P. (1948) The interpretation of statistical maps. - Joumal of the Royal Statistical Society. 10. 243-251. o.

Nemes Nagy J. (1998) A tér a társadalomkutatásban. Hilscher Rezsö Szociálpolitikai Egyesület, Budapest.

Prajczer T. (2004) A választási térinformatika lehetöségei. XIV. Országos Térinformatikai Konferencia, Szolnok. (www.otk.hu)

Yano, K. (2001) GIS and quantitative geography, - GeoJournal. 52. 173-180. o.

\section{SPACE, INFORMATION AND SOCIETY: GIS TOOLS IN SPATIAL RESEARCH OF THE SOCIETY}

\section{ÁKOS JAKOBI}

The opening of GIS as well as the recognition of possibilities in GIS solutions leads towards new disciplinary connections among different professions. An explicitly strong relation can be assumed between GIS and geography, which also consider spatial data very important. Also social geography wanted to be involved in this kind of connection, building mainly new interdisciplinary relations with GIS. The opening towards each other resulted the evolution of new methods and techniques, which - from the perspective of each discipline utilize the tools of the other profession. These innovations brought also changes in approach, as well as the possible evolution of new development directions. This paper aims at describing the possibilities of using GIS techniques in spatial researches of the society and tries to widen the knowledge about social GIS beyond simple digital cartography. 